Bractwa rozpowszechniły publiczny kult Serca Jezusa w Polsce. Już P. Wiązkiewicz wprowadzając pierw.sze bractwo do kościoła pijarów w Warszawie podkreślił, że pragnie w ten sposób zaprowadzić w Królestwie Polskim publiczną cześć Najśw. Serca, ponieważ jest ona tutaj nieznana.

Doniosłość roli, jaką odegrały bractwa w rozwoju tego kultu dokumentuje fakt, że ná ich istnienie i działalność powoływano się przy wysyłaniu próśb do Stolicy Apostolskiej w sprawie wprowadzenia Mszy św. i brewiarza o Najśw. Sercu ${ }^{11}$.

W porównaniu z innymi wspólnćami religijnymi zajmującymi się pracą gospodarczą, społeczno-charytatywną, oświatowo-kulturalną czy wychowawczą, bractwo Serca Jezusowego miało charakter ascetyczno-dewocyjny. Nie odcinając się od praktykowania miłości bliźniego w różnych dziedzinach, za główny cel swojej działalności stawiało pogłębienie pobożności i życia chrześcijańskiego. Różniło się od innych konfraternii tego typu tym, że podkreślało przede wszystkim duchowość chrystologiczną. Szerząc nabożeństwo do Najśw. Serca zbliżało ludzi do osoby Jezusa Chrystusa, który w chrześcijaństwie zajmuje miéjsce centralne.

Kraków

KS. CZESEAW DRĄŻEK SJ

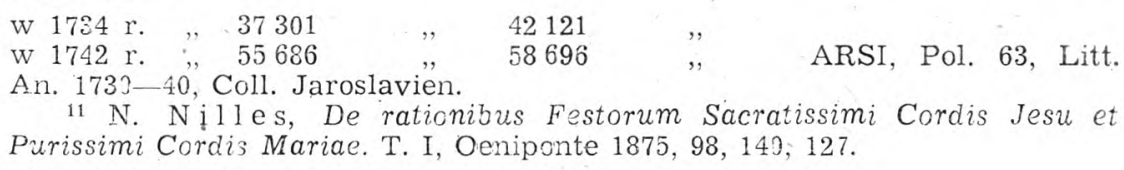

Ks. Tarsycjusz Sinka CM

\title{
DZIEJE | CHARAKTERYSTYKA POLSKICH PIEŚNI NABOŻNYCH KU CZCI ŚWIĘTEGO JÓZEFA
}

Polskie pieśni pobożne ku czci św. Józefa pojawiły się w połowie XVII wieku. Był to okres rozwoju kultu św. Józefa, okres organizowania specjalnych nabożenstw ku jego czci. W ich skład między innymi wchodzily pieśni. ${ }^{1} \mathrm{~W}$ porównaniu z inymi krajami chrześcijańskimi, zwłaszcza Niemcami, gdzie pieśni nabożne w języku ludowym pojawiły się najwcześniej, Polska nie byla tutaj krajem zapóź-

1 T. Sinka, Najstarsze polşkie pieśni nabożne ku czci świętego Jó$z e f a$, Gorzowskie Wiadomości Kościelne 19 (1976) 330—338. 
nionym. Wedlug Wilhelma Bäumknera pierwsza niemiecka pieśń nabożna ku czci św. Józefa „Mit Frewd heb ich zu loben an" pochodzi z lat 1649 i $1676 .{ }^{2} \mathrm{~W}$ języku polskim natomiast pieśń „Witay Oycze Stworcy Twego" pochodzi z 1660 roku ${ }^{8}$. Może to być nawet rok 1645, gdy uwzględni się Godzinki o św. Józefie ${ }^{4}$, których hymn „Józefie z pokolenia Dawida wybrany" śpiewano także osobno jako pieśn nabożną. Odtąd zasób polskich pieśni nabożnych ku czci św. Józefa stale wzrastał. Z trzech ubiegłych wieków zachowało się ich ponad osiemdziesiąt. Zaledwie kilka z nich śpiewa się nadal po kościołach. Wszystkie natomiast stanowią materiał do badań nad kultem św. Józefa w Polsce ${ }^{5}$.

W swojej treści polskie pieśni nabożne ku czci św. Józefa, zależnie od czasu ich powstania, odzwierciedlają różne prądy duchowości chrześcijańskiej. Teksty starszych pieśni cechuje zwrot do Pisma św. i pewien pesymizm w stosunku do natury ludzkiej.

Religijność oparta na Piśmie św. zaczynała pojawiać się już w pocz:tkach XVI wieku. Zatriumfowała jednak a'opiero po soborze trydenckim pod wpływem reformacji, która w dziedzinie religii w imię zasady sola scriptura odrzucała wszystko, czego nie zawiera Pismo św. ${ }^{6}$. Stąd proza kaznoóziejska baroku, hagiografia i liryka obfitowały w cytaty z Pisma św. ${ }^{7}$ Sebastian Grabowiecki († 1607) z Biblii i Ojców Kościoła czerpał motywy do swojej poezji ${ }^{8}$. Kaznodzieje: Justyn Zapartowicz, Adam Opatowczyk i inni ${ }^{9}$, material czerpali z Biblii, nauki Ojców Kościoła i teologów. Wreszcie polskie piéśni nabożne ku czci św. Józefa, jakie pojawiły się w okresie baroku, mają charakter biblijny i teologicznie poprawny ${ }^{10}$. Opiewają one św. Józefa jako potomka Dawida (Mt 1, 1-16. 20; Ek 2, 4; 3, 23-31), jego wynies:enie do godności małżonka Maryi (Mt 1, 19; Ek 1, 27), tajem-

2 W. Bäumker, Das katholische deutsche Kirchenlied in seinen Singweisen von den frühesten Zøiten bis gegen Ende des siebzehnten Jahrhunderts, II, Freiburg i. Br. 1883, 156.

" Dojra myśl wesotego sumienia (rhytmy polskimi wy...na) przez Adama z Konarzzwa Konarzewskiego na większa chwate Boza roku 1660. Rkps 59, Biblioteka Karmelitanek w Krakowie na Wesołej. Tekst w nawiasach mocno zniszczony.

4 Cfjicium abo Godzinki Iozepira S. Patryarchy y Oblubienca Naświętszəy Panny, Kraków 1645, A. Piotrowezyk.

5 T. Sink a, Materiaty do kultu świętego Józefa w polskich pieśniach nabożnych, Cościkowo-Paradyż 1973 (maszynopis).

6 K. Górski, Dzieje życia wewnętrznego w Polsce, w: Księga Tysiaclecia katolicyzmu w Polsce, I, Lublin 1939, 330.

7 J. Ryte1, Barok, w: Literatura polska od średniowiecza do pozytywizmu, Warszawa 1975, 213.

8. Tamże, 134.

9 K. Górski, Od religijności do mistyki. Zarys dziejów życia wewnętrznego $w$ Polsce, Lublin 1962, 123.

10 Należą tu na. przykład pieśni: „Józefie z pokolenia Dawida wybrany” i „O Józefie uwielbiony, z krwie Dawida ozdobiony". 
nicę cudownego poczęcia, która była przyczyną jego bolesnej rozterki (Mt 1, 18-25) i jej wyjaśnienie (Mt 1, 19), wędrówkę do Betlejem i narodzenie Zbawiciela (Mt 2, 18-25; Łk 2, 1-7), ofiarowanie Dzieciątka w świątyni i epizod z Symeonem ( $\mathrm{kk}$ 2, 22-38), pokłon pasterzy (Łk 2, 8-20), hołd magów (Mt 2, 1-12), ucieczkę do Egiptu (Mt 2, 13-18), powrót do Nazaretu (Mt 2, 19-23; Łk 2, 39-40),

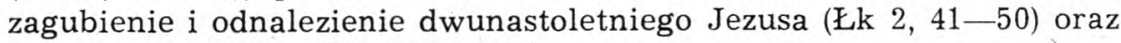
życie w Nazarecie (Ek 2, 51-52).

Postawę raczej pesymistyczną w stosunku do natury ludzkiej zajął św. Ignacy Lojola i jego zakon. Rozwinęła się ona pod wpływem mistyki niderlandzkiej. Spowodowała silny zwrot woli do Boga. Ten sam pesymizm przymierza o zabarwieniu indywidualistycznym wystąpił w zakonie karmelitańskim, zreformowanym przez św. Teresę od Jezusa i św. Janá od Krzyża ${ }^{11}$. Do Polski ten typ pobożności sprowadzili jezuici i karmelici. Przyczyniły się do tego również tłumaczenia dzieł Ludwika z Grenady, Teresy od Jezusa i Jana od Krzyża. Pogardzanie sobą i całkowite oddanie się Bogu, to naczelne jakby hasła tego nurtu. Uwydatniły się one w liryce religijnej. Przykładem może być liryka ks. Józefa Baki, w której serce człowieka porównuje on do chlewa. W jednym z monologów-lirycznych pisze: „Uczyń mnie gąbką czy miotłą Twoją". Podobnie pisze Beniowska: „Obym się mogła stać ja pieluchami" ${ }^{2}$. Z tego okresu zachowało się kilka pieśni nabożnych ku czci św. Józefa, które reprezentują ten typ pobożności ${ }^{18}$. Na przykład w pieśni „Józefie Święty Boga Wcielonego" autorka, prawdopodobnie karmelitanka, pisze: „Pragnie stajenki między bydlętami, Ktosz ja bydlę z jego affektami" ${ }^{14}$. Pieśni te nacechowane efektywną i manieryczną czułostkowością nie weszły do repertuaru pieśni żywych.

Niektóre pieśni polskie nabożne ku czci św. Józefa zawierają akcenty patriotyczne. Jest to moment charakterystyczny dla duchowości polskiej. W świadomości społeczeństwa polskiego patriotyzm i katolicyzm szły $\mathrm{w}$ parze. Treści religijne zespalano $\mathrm{z}$ wartościami patriotycznymi, ze służbą dla ojczyzny. Nic więc dziwnego, że znalazło to swój wyraz także w pieśniach nabożnych ku czci św. Józefa, pochodzących zwłaszcza $\mathrm{z}$ okresu rozbiorów Polski ${ }^{15}$.

11 K. Górski, Od religijności, 68.

12 A. Gwóźdź, Kolęda postycka doby Oświecenia, Znak 27 (1975) 1509.

13 Np.: „Witay Iozefie Krolow Osobo”, Iozefie Swięty Boga Wcielonego", ,Iozefie z pokolenia Dawida zrodzony".

14 Pieśni różne, wyjęte z różnych Cancyonałow o Bozym Narodzeniu, o Męce Pańskiey y insze wszelkiego czasu służace w iedno zebrane Roku Pańskiego 1744-tego na chwalę Panu Bogu, Pannie Przenayświętszey. Rkps 112, Biblioteka Karmelitanek w Krakowie na Wesołej.

${ }_{15}$ Np.: „Witay Iozefie, kochany Patronie”, „Szczęśliwy, kto-sobie Patrona" (o św. Józefie Kaliskim), „Józefie święty, spójrz na nas z nieba”, „O Stróżu Boży”. 
Nowsze pieśni ku czci św. Józefa coraz bardziej zatracają charakter biblijny. Przeważa w nich charakter błagalny. Żywotne sprawy czlowieka wychodzą na plan pierwszy. Nie ma prawie takiej potrzeby duchowej czy doczesnej, która nie znalazłaby w nich odbicia. Cechuje je ogromne zaufanie do „potężnego Patrona” i „Szafarza łask Bcskich". Można mu zaufać, skoro sam Bóg powierzył mu swojego Syna.

Na dalszym nieco planie mieści się w pieśniach idea naśladowania cnót św. Józefa, zwłaszcza jego miłości do Boga i bliźniego, czystości, prawości, wierności i posłuszeństwa.

W formie poetyckiej i modlitewnej lud otrzymywał w pieśniach syntezę danych biblijnych i dorobku tradycji w zakresie józefologii wraz z ideałem życia w służbie Boga i bliźniego.

Gościkowo-Paradyż

KS. TARSYCJUSZ SINKA CM

-,Postać Józefa - robotnika zaabsorbowała w czasach ostatnich liturgię tak bardzo, że nawet jakby przesłoniła tę idee, która wraz z kultem Józefowego ojcostwa w rodzinie nazaretańskiej kazała widzieć w nim także opiekuna - poniekąd ojca - całego Kościoła. Ten, który był za swego życia ziemskiego opiekunem Chrystusa historycznego, musi być teraz w swym życiu chwalebnym opiekunem Chrystusa mistycznego, tj. Kościoła. Ta wspaniała myśl liturgii związana $z$ dawniejszym świętem obchodzonym w środę po drugiej niedzieli po Wielkanocy..., myśl pełna głębi i zarazem jakiejśs szczególnej wyrazistości teologicznej, teraz jakby ustąpiła na drugi plan wobec społecznej roli św. Józefa. Widać, że Kościół wciąż jest w trakcie odczytywania tej postaci, że wciąż odnajduje w niej bogactwo zrazu nieznane lub raczej nie ujawnione, dzieje ludzkości też na swój sposób do tego pomagają".

Karol kard. Wojtyła, „Aby Chrystus się nami postugiwal”, Kraków 1979, 83-84. 